\title{
CHRISTIAN HYMNOGRAPHIC REPRESENTATION OF THE STATE OF THE SOULS IN HELL
}

\author{
PhD. Cosmin SANTI, \\ "Faculty of Orthodox Theology and Education Sciences, \\ „Valahia” University, Târgovişte, \\ ROMANIA, \\ E-mail: santicosmin@yahoo.com
}

\begin{abstract}
Of an irreducible antagonism, both states, heaven and hell, are eternal. Our earthly life, of faith and communion with the Heavenly Father or of faithlessness and noncommunion with God, is extended in the eternity. Our reaching the heaven or the hell is the natural and logical consequence of our actions and not the result of an arbitrary judgment of God. If our paradisiacal life means walking towards perfection and then a continuous progress, a continuous enlightenment of rational creatures as theomorphs, once you reach the end, the lives existing in hell go the completely opposite direction. For demons coexisting with God is impossible; they do not match Him, in other words, they cannot see His uncreated glory. The hell is the stillness in a state of separation and hatred of God, due to sin, which is the disunion. The eternal damnation resembles an endless nightmare and consists in: taking distance from God, feeling remorseful, weeping and gnashing of teeth, tortures which will last day and night to all eternity.
\end{abstract}

Keywords: hell; judgment; God; devils; sin;

\section{INTRODUCTION}

"In Orthodoxy, religious books constitute a full treasure, alive, present and eternal of Christian religious experience, the answer given by the believer of his word to God's call. Books of ritual were overwhelmingly important for the Church and for its believers. All theory of the Church, all dogmas are explained and translated for the ordinary believers, accessible to them through text books of cult. They have as main purpose the catechetical teaching; they aim to introduce the believer into a mysterious atmosphere, become closer to God, thus having a charismatic purpose; a third goal is that we can highlight these liturgical embodiments having lateritic role; and not least the aesthetic purpose, beauty cult, along with the church music have led to a unique art and rare beauty"l.

If our paradisiacal life means walking towards perfection and then a continuous progress, a continuous enlightenment of rational creatures as theomorphs, once you reach the end, the lives existing in hell go the completely opposite direction. For demons, coexisting with God is impossible; they do not match Him, in other words, they cannot see His uncreated glory. They believe, but they do not communicate with Him. If paradisiacal life is friendship, hell is unfriendship and non-communion, both in relation to God and in relation

\footnotetext{
${ }^{1}$ Assist. Phd. Rev. Cosmin Santi, „Christian Cult And Liturgical Books After The Edict Of Liberty (313)”, in Teoloigie şi Viaţă, 2015, nr. 5-8, pp. 133,136
} 
to others. "The frightening darkness of death unsettles my soul and the demon inquiring always makes me puzzle and wince me"2.

Saint Maximus the Confessor shows that God also loves and cherishes the one from hell, however the latter's unhappiness lies in his being apart from Him and spending time with those who hate Him and whom he hates himself: "And more agonizing and horrifying than any anguish is being forever around those who hate you and are hated...and being separated from the one who loves you and is loved" 3 .

\begin{abstract}
"Always being in torment..., would there be anything harder, a greater woe than this? Neverending eternity! This is an endless sea of which limits cannot be encompassed by the human eye; this is darkness, a precipice where the human eye cannot penetrate. When the sky grows old, like a coat; when the sun gets dark, like a fuming charcoal; when the starts fall from the sky, like the autumn leaves; when all tribes and peoples are defeated by time, like grass under the reaper's scythe stick; when the world disappears; when time gets tired of flying and stops flowing before the throne of the One Who created it, then eternity will come and all these will not even resemble a drop in its limitless ocean. Eternity is an endless beginning, a limitless space, timeless time. One thousand years resemble a day there and a day resembles one thousand years; a split second is eternity there and eternity is a split second; centuries will seep there, thousands of years over thousands of years and then any time calculation will be wasted and eternity will however set in and eternity years will be more and more numerous" 4
\end{abstract}

The Judaic religion does not know the resurrection doctrine. Any man goes down in the seol, an underground place, dark and shadowed, where there is no memory, no praise of God. The hell is where the dead, especially the sinful ones, will be thrown, as this is the home of the dead, Jesus Christ descended to hell to preach before the spirits held in prison (Luca 16, 23), or the state of the doomed, the sufferings and the eternal fire designated to the devil and his angles (Matthew 25, 41). Christ descended to hell deified to show that His light covers the darkness and the shadow of death and to set the slaves free. Jesus Christ, Who voluntarily accepts His death on the Cross, assumes the human reality all the way through the end, in all its most negative aspects, and the confrontation itself with the devil where the latter dwells and is the master, namely the kingdom of death. In fact, redemption means taking man out of hell. He descends like a king and announces His eternal victory over death and Satan, not only for the righteous, but for all, for the Christians and the ungodly ${ }^{5}$. The texts of our religious books are extremely beautiful and depict this shining and incomprehensible event as follows: "Your burying, Lord, opened the heaven to mankind; and from lewdness we were delivered and we pray to You, Our resurrecting God; have mercy on $u s "$.

"We worship to Your Cross, Lover of Mankind, as you were nailed down on the cross, life of all; Savior, you opened the heaven to the thief who came to You in faith and who had loved

2 ***, Octoihul Mare, care cuprinde slujba Învierii pe opt glasuri, Tipografia cărţilor bisericeşti, Bucureşti, 1952, Glasul al IV-lea, Marţi seară, la Doamne strigat-am, Stihirile Crucii, Stihira a VI-a, p. 321.

3 Sfântul Maxim Mărturisitorul apud Pr. Dr. Ioan Tulcan, Rai şi iad - realităţi veşnice, în „Mitropolia Banatului", XXXIX (1989), nr. 4, p. 47

${ }^{4}$ S.A.Arhanghelov, Tainele vieţii viitoare, traducere de Climent I. Bontea, Editura Bunavestire, Bacău, 2007, p. 165 .

${ }^{5}$ Pr. Prof. Dr. Ion Bria, Dicţionar de Teologia Orotdoxă A-Z, ediţia a II-a, Editura Institutului Biblic şi de Misiune al Bisericii Ortodoxe Române, Bucureşti, 1994, p. 194.

6 ***, Penticostarul, adică sfintele slujbe de la Duminica Paştilor până la Duminica Tuturor Sfinţilor, Editura Institutului Biblic şi de Misiune al Bisericii Ortodoxe Române, Bucureşti, 1999, Vineri în Săptămâna Luminată, la Utrenie, la Laude, glasul al VI-lea, Stihira I, p. 51. 
the pleasures of life and yet confessed to You: Jesus, remember me! Take us just you took him, for we say: We all sinned, and do not forget us for You are merciful!"7 "Your crucifixion opened the paradise to men and You raised men from the dead, You are our Life; and You rose and defeated death with Your power, and You truly unified the earthly and the heavenly; and You filled with unspoken joy the Apostles, Words of God, and You gave them peace" 8

In addition to its soteriological meaning, this event has both a christological and an eschatological meaning, as Jesus Christ descended to hell with His soul while His body was in the grave, as one can see in the troparion above, which means that, upon death, the rational soul or the human personality is not destroyed, but awaits resurrection of the body ${ }^{9}$, which will take place upon the eschatological time of the rise from the dead at the end times, just as we say in the Creed at each Liturgy. "If the Savior came down to those tied like a dead, the dead of all times rose along with Him and said: Glory to Your power, God"10. "Christ has risen, by untying the ties of Adam the first human creation and crashing the power of hell. Dare. All dead, for death was murdered, and hell was ravaged with it and Christ took His kingdom, the One who was crucified and rose. He offered us the harmlessness of the body; He will raise and resurrect us and will make us worthy of His glory, in joy, all who truthfully and dearly believed in Him" $"$.

"You let Yourself nailed down on the cross, You capable of great endurance, you let yourself lie down in the grave like a dead man, You life giver, Your death crushed the mastery of death with Your own death, You strong, the hell guards winced; You raised the dead of all times, like a Lover of mankind"12

\section{THE HELL OR DISTANCE FROM GOD}

The hell is the stillness in a state of separation and hatred of God, due to sin, which is the disunion. The hell lies in the dark, infernal aspect of human condition ${ }^{13}$, in all characteristics of man's life and disobedience to God and His commandments.

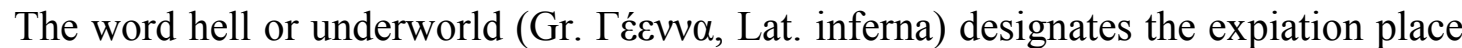
following death, the place where all unredeemed souls go; in the Orthodox iconography (Icon of the Doomsday), the hell is depicted like a river of fire, somewhere in the depth of the earth, where the sinful souls are thrown and subjected to all sorts of tortures (tormenting fire $)^{14}$. At the end of the Parable of the Bags of Gold spoken on the Mount of Olives, the hell is also described as a place of punishment and great torture in the afterworld. This is the parable where Jesus tries to prepare His listeners for the afterlife, until today, when the sinners will be thrown "in the farthermost darkness", where "there will be weeping and gnashing of teeth" (Matthew 25, 30; 24, 51). "Let me not come to the weeping land and see

\footnotetext{
${ }^{7}$ Penticostarul, Vineri în săptămâna a doua după Paşti, la Utrenie, după întâia Catismă, Sedealna Crucii, glasul I, pp. 79-80.

${ }^{8}$ Penticostarul, la Stihoavnă, Stihirile Praznicului, Stihira I, glasul al IV-lea, p. 81

${ }^{9}$ Pr. Prof. Dr. Ion Bria, Dicţionar de Teologia Orotdoxă A-Z, ediţia a II-a, Editura Institutului Biblic şi de Misiune al Bisericii Ortodoxe Române, Bucureşti, 1994, p. 194

$10 * * *$, Octoihul Mare, Glasul al V-lea, Duminică dimineaţă, alt Canon al Prea Sfintei Născătoarei de Dumnezeu, Peasna a 4-a, Stihira a VI-a, p. 380

11 ***, Triodul, care cuprinde slujbele bisericeşti de la Duminica Vameşului şi Fariseului până la Sfânta Înviere, Editura Institutului Biblic şi de Misiune al Bisericii Ortodoxe Române, Bucureşti, 2000, Sâmbăta Lăsatului sec de carne, la Utrenie, la Laude, Stihira a IV-a, glas VIII, p. 37

12 ***, Octoihul Mare, Duminică la Utrenie, Glasul I, Sedealna a II-a, p. 16

${ }^{13}$ Pr. Prof. Dr. Ion Bria, Dicţionar de Teologia Orotdoxă A-Z, ediţia a II-a, Editura Institutului Biblic şi de Misiune al Bisericii Ortodoxe Române, Bucureşti, 1994, p. 195

${ }^{14}$ Pr. Prof. Dr. Ene Branişte şi Prof. Ecaterina Branişte, Dicţionar enciclopedic de cunoştinţe religioase, Editura Diecezană, Caransebeş, 2001, p. 246
} 
the place of darkness, My Lord, Words, or be thrown out of Your world, bound hand and foot, with my harmlessness garments filthy, I the unworthy" ". "The river of fire torments me, softens me, the gnashing of teeth and the depth darkness torture me"16.

The Divine Gospel shows us that the hell is a place of torture and torment (Matthew 13, 35; Luke 16, 23). As for the sorts of different works assigned to people in hell, the same testimonies of the Holy Gospel tell us that the hell hosts the burning fire and the undying worms: "Where their worm dieth not, and the fire is not quenched...." (Mark 9, 44, 46). Both body and soul suffer in hell: "If your right eye causes you to sin, gouge it and throw it away. It is better for you to lose one part of your body than for your whole body to be thrown into hell." (Matthew 5, 29). In hell there is punishment and eternal fire: "If your hand or your foot causes you to stumble, cut it off and throw it away. It is better for you to enter life maimed or crippled than to have two hands or two feet and be thrown into eternal fire" (Matthew 18, 8 ). In hell there is a furnace of fire and brimstone (Apocalypse 20,10), the eternal oven and the gnashing of teeth (Matthew 13, 50), the fire of hell (Matthew 5, 22); the hell is tartarus, where it is abominably cold and freezing (2 Peter 2, 41), it is dark (Judas 6, Romans 13, 12), it stinks unbearably (John 11, 39, Isaiah 34, 3), weeping, excruciating famine etc.; there will be huge despair in hell, and there will no longer be time for redemption, for the door of God's mercy has closed for those who are not prepared and penitent.

"I weep and I gripe when I start feeling the eternal fire, the farthermost darkness and the tartarus, the abominable worm and the never-ending gnashing of teeth, and the pains which are to go through the ones did all the wrongs, and who deceivingly infuriated You, the Very Kind, of which I am one and the first, the wretch. You Judge, have mercy on my soul and redeem me"17

In hell there is eternity, endless torture, and it is to these endless works that Jesus the Savior refers when He says: "Then He will say to those on his left, 'Depart from me, you who are cursed, into the eternal fire prepared for the devil and his angels. Then they will go away to eternal punishment, but the righteous to eternal life" (Matthew 25, 41, 46). Then let us work incessantly on our reformation and pray to God by saying: "Forgive me, Father, Your Slave, so that You do not abandon me to the most bitter tortures, to the atrocious angles, among whom one may not find peace" ${ }^{\text {"18 }}$. Save me, Lord from the gates of hell; save me from the abyss and the deepest darkness, from what lies under the earth and from the burning fire and from any other eternal punishment ${ }^{19}$.

We can escape the devil's influence and his conspiracies only if "we participate to God's love, if we unify with the others in Church, which truly represents the sharing of godly life; it may be weakened and destroyed if man ignores Satan's conspiracies. The Church has two aspects: one positive, i.e. love, union and immortality shared with one another and saints into Christ, and one negative, defeated in the body of Christ by those who live into Christ, beyond death. Christology represents the positive aspect of the Church, which is however influenced by the biblical demonology - the negative key factor, which

\footnotetext{
15 ***, Triodul, Duminica Lăsatului sec de carne, La Utrenie, Canonul-alcătuire a lui Teodor Studitul, Cântarea a 4-a, Stihira a IV-a, glas al VI-lea, p. 43.

${ }^{16}$ Triodul, Cântarea a 5-a, Stihira a II-a, glas al VI-lea, p. 44

${ }^{17}$ Triodul, Duminica Lăsatului sec de carne, la Vecernie-Sâmbătă Seara, la Doamne strigat-am..., Stihira a IVa, glas al VI-lea, p. 40

${ }_{18}$ Triodul, la Utrenie, Canonul-alcătuire a lui Teodor Studitul, Cântarea a 5-a, Stihira a III-a, glas al VI-lea, p. 44.

${ }^{19}$ Triodul, Cântarea a 6-a, Stihira a VI-a, glas al VI-lea, p. 45
} 
determines both Christology and ecclesiology, which are both impossible to comprehend without a proper understanding of Satan's work and methods ${ }^{20}$. Nevertheless, the Incarnation of our Lord, Jesus Christ, His miracles, His Passions, His Crucifixion, His Death, His Descend into Hell, and more importantly His Rise from the dead, destroyed the gates of hell, broke the chains of demons, the power, the yoke, the slavery of the devil, and re-established the harmony between man and God, once and for all, and this is praised and commended in most texts of religious hymns of the Pentecostarion books, which are extremely beauteous:

"Let the creature be joyful and flourish like a lily for Christ has risen, Where is your courage, death? Let us scream. Where is your victory, hell, You were made to fall by the one who raised us like a Gracious"21. "Christ, with Your chosen life-creating death, you shattered the gates of hell like a God, You opened the old heaven for us, and raising from the dead, You saved our lives from rottenness" 22 . "God, you smashed the gates of hell and destroyed death with Your great power and together You raised the dead sleeping in the dark for centuries, with Your godly and gracious Resurrection, like the King of all and God, Almighty"23.

The godly providence is a work which encompasses the whole creation. According to the patristic theology, if God takes back His breath of Life, everything will turn into nothing. The creation is not self-sufficient since it has no existence in itself. God makes creatures and things be, live, reason. God deifies creatures and things in line with their receptivity, depending on their nature or volition. It is due to this care of God for creation in general, and for man in particular, that He makes some people have feelings and experiences of hell ever since this lifetime, so that they may be awaken to reality and to a more virtuous life. "Hell is dead; dare, human beings! For, being crucified on the cross, Christ threw the sword against it and it lies dead, for it was deprived and emptied of all those it kept inside ${ }^{24, "}$.

Saint Mark of Ephesus believes that what is seen in the hell experiences is "often a face of future tortures, and not a literal embodiment of the present state of those who await the Doomsday in hell, 25 .

Nevertheless, the hostility towards God, which is also hell, is unforgivable. Not because God's mercy has some limits or boundaries, but because the man, who constantly looks away from God, reaches the extreme limit of enmity from which there is no turning back. If man stands against the Holy Spirit, the Holy Spirit may no longer bring him back to penitence. The soul of an understanding creature may soften only through the godly grace of the Holy Spirit, without which it will surrender to pride and darkness ${ }^{26}$.

\footnotetext{
${ }^{20}$ Arhiepiscopul Hrisostom de Etna, Elemente de psihologie pastorală ortodoxă, ediţia a II-a, traducere de Daniela Constantin, Editura Bunavestire, Galaţi, 2003, p. 65

21 ***, Octoihul Mare, Glasul al VI-lea, Duminică dimineaţă, alt Canon, al Crucii, Stihira a II-a, p. 476.

${ }^{22}$ Octoihul Mare, Duminică dimineaţa, Al doilea rând de Sedelne ale Învierii, Slavă..., p. 467

${ }^{23}$ Octoihul Mare, Glasul al VII-lea, Duminică dimineaţă, la Laude, Stihira a V-a, pp. 563-564

24 ***, Penticostarul, Duminica a treia după Paşti, a Sfintelor femei mironosiţe şi a Dreptului Iosif, la Utrenie, Canoanele, Canonul Mironosiţelor-alcătuire a lui Andrei Criteanul, Cântarea a 6-a, Stihira a II-a, glasul al IVlea, p. 99.

25 Sfântul Marcu al Efesului, Cuvântări împotriva purgatoriului apud Ierom. Serafim Rose, Sufletul după moarte, traducere de Dana Cocargeanu, Editura Sofia, 2007, p. 169.

${ }^{26}$ Apostazia şi antihristul după învăţăturile Sfinţilor Părinţi, Editura Sfinţii Martiri Brâncoveni, Constanţa, 2008, pp. $37-38$
} 
"I will pour my prayer to God and I will share all my misfortunes with Him; for my soul is full of mischief and my life is closer to hell now; and like Jonah I pray: God, take me out of rottenness" 27

\section{THE LAST JUDGMENT, ETERNAL LIFE OR ETERNAL DAMNATION}

After man's judgment some people will start enjoying eternal happiness, while others eternal punishment, meaning eternal tortures in hell, the place where dwell all hatred, distress and disaster, where there is only horror, torment and chaos, where one may find no joy, hope or relief (Mark 9, 44, 46, 48). The eternal separation from God and the deprivation of His gifts, the horrible remorse, the dishonesty and eternal shame, the blemishes, the insults and the curses of those who were attracted to sin by the punished, the oppressions of the demons who live with the punished ${ }^{28}$, all this will compose the picture called the hell, the Hades, the farthermost darkness, the tartarus where "there is gnashing of teeth" (Matthew 22, 13) and "the fright of harassment" (Mark 13, 14).

"Alas, my miserable soul, you will be weeping much there in remembrance of your actions, when the righteous are invited to the eternal Kingdom while you are punished for your actions in the eternal fire! Sob your heart out, weep while still here, run after Christ the Savior and cleanse your sins." 29

It is absolutely true that the ones who rejected communion with God are in hell. But those who did not lose all faith in God are also in hell, where they dwell due to their insignificant sins which took them out of the communion with God. With this faith in their souls, the hell dwellers may discover the communion with Christ and go to heaven, before the doomsday, with the help of the saints' prayers and the prayers of the ones living on earth. Prayers make the act of communion of the people on earth sprout the root of the communion tree in the soul of the hell dwellers ${ }^{30}$.

The mystery of the fact that some will be taken out of the hell before the universal judgment and others will live in hell forever and will, moreover, go to the eternal hell along with those who die and go to hell, at the end of times, is a mystery of man's freedom and of his power to strengthen himself in a negative freedom difficult to overcome. Berdiaeff admits that there is a hell resulting from the refusal of the communion with God; yet he believes that this is a subjective hell, not an ontological one, and states that it may not last forever $^{31}$.

Saint Joan of Damascus says: "God also offers the devil what is forever good. But the devil refuses to receive it. And in the century to come God offers everyone the good things. However, each participates to what is good as each made himself worthy of it"32 [32]. This is why God is not the source of all devil's eternal tortures, the devil actually tortures itself.

All those who will not be able to get out of hell until the universal judgment, will never be able to leave it. The hell punishments are different from person to person, as their

\footnotetext{
27***, Mineiul pe Februarie, Editura Reîntregirea, Alba-Iulia, 2002, Ziua a opta, la Utrenie, Canoanele, Cântarea a 6-a, Irmosul, glasul al VIII-lea, p. 85

$28 * * *$, Apostazia şi antihristul ..., pp. 80-81.

$29 * * *$, Octoihul Mare, Glasul al VIII-lea, Duminică seara, La Doamne strigat-am, Stihirile de umilinţă,, Stihira a II-a, p. 651.

${ }^{30}$ Pr. Prof. Dr. Dumitru Popescu, Iisus Hristos - Pantocrator, Editura Institutului Biblic şi de Misiune al Bisericii Ortodoxe Române, Bucureşti, 2005, p. 397

${ }^{31}$ Pr. Prof. Dr. Dumitru Stăniloae, Teologia Dogmatică Ortodoxă, ediţia a II-a, vol. III, Editura Institutului Biblic şi de Misiune al Bisericii Ortodoxe Române, Bucureşti, 1997, p. 177.

${ }^{32}$ Sfântul Ioan Damaschin apud Pr. Dr. Ioan Tulcan, art.cit., p. 47
} 
sins are different. The reward will be in line with everybody's actions, depending on how conscious and free they were in performing such actions. Therefore, hell continues to be a possibility for each individual; yet it depends on us, people, whether this possibility becomes a reality or not.

\begin{abstract}
"God, when you judge them all, which of the people on earth, who live in the middle of their passions, will suffer? Because then, the burning fire and the undying worm will soar above the forever punished",33
\end{abstract}

There are opinions according to which the eternity of hell would bring sadness into God's life, which is heaven. This apocatastasis argument relies on the fact that God, saints and eternal life are essentially love and memory of love. Love is also memory, memory of love mainly. The redeemed are eternally linked to sinners by mere memory. When in need, the apocatastasis followers were calling Saint Isaac the Syrian who was also praying and shedding tears for demons. He says that love may dwell in hell and not destroy it, since this is exactly what hell is: the flames of remorse, the flames of love denied ${ }^{34}$. On the contrary, Saint Catherine of Siena says: "Love may not remain in hell, it would crush it; it would be easier to destroy hell than let love stay in it forever" 35 . The idea that hell introduces sadness into God's life lies in a certain conception regarding love and God's feeling which starts from the axioms that God is so kind that He may not help forgiving, that His love is an irrepressible miracle by itself, and there is no greater miracle than loving the falling sinners, and the fact that Christian teachings and mystic experience unanimously show that the Spirit of God teaches us to love everything. God's love certainly goes beyond the justice that people can understand. Without being in contradiction or affecting justice, love may be imagined as an addition to it, a redundancy beyond justice and yet never able to destroy such justice. We may be right in asserting that, in a super-human sublime meaning, God's justice is in fact love. God's love for those living in hell is not sheer sentimentality or compassion, but always control and conscious precise action. His love does not even exclude a certain abandonment on God's side. God's real and definitive love to us all does not automatically mean sadness in a human sense. Sadness seems to be a sort of love weakening. The action of the love shown to those in heaven is extremely real, yet the response to it is different ${ }^{36}$. "Blessed Virgin Mary, who gave birth to the One Righteous Forgiving Judge, Jesus Christ our Lord, save me from the judgment and the fire and the torture which were inflicted on me by my delight for sins",37.

Hell exists and persists because there is persistence in not confessing our sins and this means eternity of hell. Hell persists and settles down because the obstinate refusal of Life and Truth means final stillness; because there is also a total separation from the being and the truth, from the others. The eternity of hell appears possible because we have both the experience of refusing God and the stillness of such refusal, which refusal eventually turns

\footnotetext{
33***, Triodul, Duminica Lăsatului sec de carne, la Utrenie, Canonul-alcătuire a lui Teodor Studitul, Cântarea a 8-a, Stihira a II-a, glas al VI-lea, p. 48

${ }^{34}$ Pr. Conf. Dr. George Remete, Suferinţa omului şi iubirea lui Dumnezeu, Editura Institutului Biblic şi de Misiune al Bisericii Ortodoxe Române, Bucureşti, 2005, pp 101, 102.

${ }^{35}$ Hans Urs von Balthasar, Mic discurs despre iad, traducere de Alexandru Sahighian, Editura Anastasia, 1994, p. 67

${ }_{36}$ Pr. Conf. Dr. George Remete, Suferinţa omului şi iubirea lui Dumnezeu, Editura Institutului Biblic şi de Misiune al Bisericii Ortodoxe Române, Bucureşti, 2005, pp. 103, 104, 105, 106

37 ***, Triodul, Miercuri dimineaţa în întâia săptămână a Sfântului şi Marelui Post, Tricântarea, Cântarea a 9a, Stihira a IV-a, a Născătoarei de Dumnezeu, glasul al II-lea, p. 154
} 
out to be a frailty. Hell is the refusal of God's eternal love or the refusal to love. The refusal to love becomes at a certain point in time the inability to love. Saint Maximus the Confessor says:

"For we contorted the right feeling of love and we embedded a twisted movement in our hearts, and so we corrupted its lack of suffering and we perverted it. And therefore, we unawares caused on us the hatred of choice, like a worm, the damage, and we dug within ourselves, through lies, a much more unfair feeling, which made it impossible for us to unify with the Honest Righteous God ${ }^{, 38}$.

\section{CONCLUSIONS}

We can conclude with the words of the Russian theologian Paul Evdokimov whose opinion on hell is: Therefore the eternity of heaven and the eternity of hell have to be seen from the perspective of God's supreme justice. God Who rewards actions of the righteous and punishes the sins of the non-righteous with eternal tortures.

\footnotetext{
"The hell of the divine love is the celestial dimension of the hell, the divine vision of the man who sank in the darkness of his loneliness" 39 . "How will hell endure Your entrance, God, and how will it not crush and darken at the sight of Your blinding light?" ${ }^{40}$. Oh, Savior, voice of spoken God and godly power of Your mastery through which you pulled down the gates of hell and of the all-eating death! Take me away from my passions, just like You did with Lazarus, your four-day-long dead friend" "Your Resurrection lightened everything up, God, and the heaven itself opened; and all creation praises and worships You forever" "42; "And so leaving this life with the hope of the eternal life, let me reach the never-ending rest, where lies the undying voice of the worshippers and the endless sweetness of those who can see the unspoken beauty of Your face" ${ }^{43}$.
}

\footnotetext{
${ }^{38}$ Sfântul Maxim Mărturisitorul, Scrieri, vol. II, în P.S.B., nr. 81 apud Pr. Conf. Dr. George Remete, op.cit., p. 122.

${ }^{39}$ Paul Evdokimov, Iubirea nebună a lui Dumnezeu, traducere de T. Baconsky, Editura Anastasia, Bucureşti, 1993, p. 10

40 ***, Triodul, Slujba Sfintelor şi Mântuitoarelor Patimi ale Domnului Iisus Hristos, În Sfânta şi Marea Zi Sâmbătă, Denia de Vineri seara când se cântă şi Prohodul Domnului, Starea I, Troparul 10, glasul al V-lea, p. 649

${ }^{41}$ Triodul, Sâmbătă în săptămâna Floriilor, la Utrenie, Canonul-alcătuire al lui Teofan, Cântarea a 5-a, altă Tricântare, Stihira a II-a, glasul al II-lea, p. 522

42 ***, Penticostarul, Marţi în Săptămâna Luminată, în Sfânta şi Marea Duminică a Paştilor, la Vecernie, la Doamne strigat-am..., Stihirile Învierii, glasul al III-lea, Stihira a II-a, p. 36

43 Penticostarul, Rugăciunile de mulţumire după dumnezeiasca Împărtăşire, Rugăciunea întâia a Sfântului Vasile cel Mare, p. 320
} 


\section{REFERENCES:}

[1] ***, Mineiul pe Februarie, Editura Reîntregirea, Alba-Iulia, 2002,

[2] ***, Octoihul Mare, care cuprinde slujba Învierii pe opt glasuri, Tipografia cărţilor bisericeşti, Bucureşti, 1952,

[3] ***, Penticostarul, adică sfintele slujbe de la Duminica Paştilor până la Duminica Tuturor Sfinţilor, Editura Institutului Biblic şi de Misiune al Bisericii Ortodoxe Române, Bucureşti, 1999,

[4] ***, Triodul, care cuprinde slujbele bisericeşti de la Duminica Vameşului şi Fariseului până la Sfânta Înviere, Editura Institutului Biblic şi de Misiune al Bisericii Ortodoxe Române, Bucureşti, 2000,

[5] Apostazia şi antihristul după învăţăturile Sfinţilor Părinţi, Editura Sfinţii Martiri Brâncoveni, Constanţa, 2008,

[6] Arhiepiscopul Hrisostom de Etna, Elemente de psihologie pastorală ortodoxă, ediţia a II-a, traducere de Daniela Constantin, Editura Bunavestire, Galaţi, 2003,

[7] Assist. Phd. Rev. Cosmin Santi, „Christian Cult And Liturgical Books After The Edict Of Liberty (313)", in Teoloigie şi Viaţă, 2015, nr. 5-8,

[8] Hans Urs von Balthasar, Mic discurs despre iad, traducere de Alexandru Sahighian, Editura Anastasia, 1994,

[9] Ierom. Serafim Rose, Sufletul după moarte, traducere de Dana Cocargeanu, Editura Sofia, 2007,

[10] Paul Evdokimov, Iubirea nebună a lui Dumnezeu, traducere de T. Baconsky, Editura Anastasia, Bucureşti, 1993

[11] Pr. Conf. Dr. George Remete, Suferinţa omului şi iubirea lui Dumnezeu, Editura Institutului Biblic şi de Misiune al Bisericii Ortodoxe Române, Bucureşti, 2005,

[12] Pr. Dr. Ioan Tulcan, Rai şi iad - realităţi veşnice, în „Mitropolia Banatului”, XXXIX (1989), nr. 4

[13] Pr. Prof. Dr. Dumitru Popescu, Iisus Hristos - Pantocrator, Editura Institutului Biblic şi de Misiune al Bisericii Ortodoxe Române, Bucureşti, 2005

[14] Pr. Prof. Dr. Dumitru Stăniloae, Teologia Dogmatică Ortodoxă, ediţia a II-a, vol. III, Editura Institutului Biblic şi de Misiune al Bisericii Ortodoxe Române, Bucureşti, 1997

[15] Pr. Prof. Dr. Ene Branişte şi Prof. Ecaterina Branişte, Dicţionar enciclopedic de cunoştinţe religioase, Editura Diecezană, Caransebeş, 2001

[16] Pr. Prof. Dr. Ion Bria, Dicţionar de Teologia Orotdoxă A-Z, ediţia a II-a, Editura Institutului Biblic şi de Misiune al Bisericii Ortodoxe Române, Bucureşti, 1994, p. 194.

[17] S.A.Arhanghelov, Tainele vieţii viitoare, traducere de Climent I. Bontea, Editura Bunavestire, Bacău, 2007, 